\title{
AULAS DE REDAÇÃO E OUTROS OSSOS
}

Tovar Nelson Pereira Junior é mestrando em Letras pela UFMG.

E-mail: tvrniu@gmail.com

O menino é

Que é a matéria

Que deveria ser mexida.

Não só seu texto-sem-poema.

O menino é

Que é a carnadura

De fazer poema,

Ou texto.

Então porque continuo

Corrigindo textos

Em vez de consertar meninos?

Deve ser que para isso

Teria de encantá-los,

Desfazer com eles a condição de bicho,

Ou máquina.

E o que menos

Os pais querem

E os outros que lhes prestam

Desserviço

É que eles virem príncipes;

O princípio diretor

De tudo aquilo que eles mesmos

Querem ser.

Então continuo nesse

Duro ofício, sacrofício,

De mexer em textos

E nunca tocar naquilo

Em que realmente deveria mexer. 